\title{
Seedling Spacing in the Nursery in Relation to Growth, Yield, and Performance of Stock
}

\author{
by
}

\author{
R. van den Driessche ${ }^{1}$
}

\begin{abstract}
In three experiments coastal and interior varieties of Douglas-fir (Pseudotsuga menziesii (Mirb.) Franco), Sitka spruce (Picea sitchensis (Bong.) Carr), white spruce (Picea glauca (Moench.) Voss), lodgepole pine (Pinus contorta var. Iatifolia Engelm) and western red cedar (Thuja plicata Donn.) were grown at a range of spacings, within drills $15 \mathrm{~cm}$ apart, at four nurseries in coastal British Columbia. In a fourth experiment the frequency distribution of seed spacings achieved with three types of precision seeders was examined.
\end{abstract}

A $1 \mathrm{~cm}$ increase in spacing increased seedling dry weight by $0.5-1.5 \mathrm{~g}$ and root collar diameter by 0.2 $0.25 \mathrm{~mm}$, up to a spacing of about $8-10 \mathrm{~cm}$. Above this spacing response was less. Height of two-year old (20 ) seedlings was increased little, or even decreased by wider spacing. Height:diameter ratios decreased sharply and shoot:root dry weight ratios decreased or remained unchanged with wider spacing. The number of needle primorida in 2-0 Douglas-fir buds increased up to a spacing of $2 \mathrm{~cm}$. The number of first and second order branches was also increased in 2-0 seedlings of this species by wider spacing. Needle dry weight and area measurements suggested Douglas-fir from wider spacing had more sun type needles than those from closer spacing, which had more shade type needles. Only small increases in root growth capacity (RGC) were associated with wider spacing. None of the precision seeders tested achieved anything like perfect precision of seed placement. With irregularity added by $10-20 \%$ non-viable seed and winter mortality, truly precision spaced stands of 2-0 seedlings could not be achieved under existing conditions. Increased spacing of $2-5 \mathrm{~cm}$ between seedlings, depending on species and nursery, was justified by yield of acceptable seedlings when culling standard was increased to a root collar diameter of about $6 \mathrm{~mm}$.

Three years after planting, survival of white spruce was increased $11 \%$ by wider spacing in the nursery. and the corresponding value for Sitka spruce two years after planting was $13 \%$. Seedlings of both species from wider spacings maintained a height and diameter advantage over those from close spacing.

\section{Résumé}

Lors de trois expériences conduites dans quatre pépinières localisées le long du littoral de la ColombieBritannique, on a fait pousser des variétés côtières et continentales de Douglas taxifolié (Pseudotsuga menziesii (Mirb.) Franco), d'épinette de Sitka (Picea sitchensis (Bong.) Carr), d'épinette blanche (Picea glauca (Moench.) Voss), de pin lodgepole (Pinus contorta var. latifolia Engelm.) et de thuya geant (Thuja plicata Donn.) suivant différent espacements dans des sillons séparés de $15 \mathrm{~cm}$. Lors d'une quatrième expérience, on a examiné la distribution de la fréquence de l'espacement des graines selon trois types de semoirs de précision.

Un accroissement de l'espacement de $1 \mathrm{~cm}$ a augmenté le poids sec des semis entre 0.5 et $1.5 \mathrm{~g}$ et le diamètre au niveau du col racinaire entre 0.2 et $0.25 \mathrm{~mm}$ et ce, jusqu'à un espacement d'environ 8 à $10 \mathrm{~cm}$ entre les plants. Au-delà de cet espacement, la réponse fut moindre. La hauteur des semis de 2 ans (2-0) a peu augmenté ou a même diminué avec un espacement plus important. Ceci a aussi amené une diminution importante du ratio hauteur-diamètre alors que le ratio du poids sec tige-racine a soit diminué ou est resté inchangé. Le nombre de nouvelles formations de bourgeons d'aiguilles pour les semis (2-0) de Douglas taxifolié a augmenté jusqu'à un espacement de $2 \mathrm{~cm}$. Pour la même essence, le nombre de branches de premier et deuxième ordres a aussi augmenté chez les semis 2-0 avec un espacement plus important. Les mesures de la surface et du poids sec des aiguilles laissent suggérer que, pour le Douglas taxifolié, un plus grand espacement donne plus d'aiguilles de lumière alors qu'un espacement plus fermé donne plus d'aiguilles d'ombrage. Un plus grand espacement n'a amené qu'une faible augmentation de la capacité de la croissance racinaire. Aucun des semoirs de précision testés n'a atteint une précision proche de la perfection pour la distribution des graines. Si on ajoute à cette imprécision, une mortalité de 10 à $20 \%$ causée par la période hivernale et par des graines non viables, la véritable précision dans l'espacement des semis 2-0 ne peut être atteint sous des conditions ambiantes. Lorsque la norme de rebut fut augmentée pour ce qui est du diamètre du col racinaire par environ $6 \mathrm{~mm}$, le rendement des semis jugés acceptables a permis de justifier une augmentation de l'espacement de 2 à $5 \mathrm{~cm}$ entre les plants, tout dépendant de l'essence et de la pépinière.

Le taux de survie avec un plus grand espacement a augmenté de $11 \%$ pour l'épinette blanche, trois ans après plantation et de $13 \%$ pour l'épinette de Sitka, deux ans après plantation. Les semis des deux essences ont maintenu un meilleur rendement en hauteur et en diamètre avec un espacement plus ouvert par rapport à un espacement fermé.

'Research Branch, Provincial Ministry of Forests, 1450 Government Street, Victoria, BC V8W $3 E 7$. 


\section{Introduction}

Current nursery practices suggest that the improvements in outplanting performance resulting from wider spacing of seedlings in the nursery are often unrecognized. Since wider seedling spacing may be a simple way of increasing quality of bare root nursery stock its implications are worth study.

Improved outplanting performance through wider spacing has been demonstrated for broadcast-sown pine species (Derr 1955, Shoulders 1961, Switzer and Nelson 1963, Shipman 1964) and for drill-sown Pinus radiata (Benson and Shepherd 1976, Bowles 1981) (Table 1). Bowles (1981) has shown that seedling spacing affects subsequent height growth and can affect survival after planting. Wider spacing increased survival in dry years (Shoulders 1961) and under frosty conditions (Bowles 1981). Survival advantages of increased spacing are only likely to be evident under adverse planting site conditions, which presumably explains why survival was not always increased by wider spacing (Table 1). Heights after planting all increased with wider spacing, except for white pine (Table 1). Relatively small size differences due to wider spacing at lifting may explain the lack of growth differences in white pine (Mullin and Bowdery 1977a).

The value of precision spacing, in which each seedling has the same growing space, has been emphasized (Chavasse 1980). In this way it is hoped to produce uniform stock and reduce culling to a minimum. Since precision seeders are now commercially available it is desirable to examine their possible advantages.

Effects of increasing seedling spacing on seedling development, culling standards, yield, and survival and growth after planting are not well known, except for Pinus radiata. This work was conducted to determine effects of seedling spacing on growth and development in the nursery of several conifers native to British Columbia. Where possible more information was obtained about outplanting performance of widely spaced nursery stock. In the process, three precision seeders were tested and the effect of spacing and culling standards on yield of acceptable seedlings was considered.

\section{Methods \\ Experiment 1}

In this experiment coastal Douglas-fir seed (from Forbes Landing) was grown at Campbell River nursery and white spruce seed (from Wansa Lake) was grown at Surrey nursery. Seed was sown in May, 1979, with a modified cereal sowing machine which spaced 7 drills $15 \mathrm{~cm}$ apart across the bed. Three within-drill spacing treatments were randomized within each of three undercutting treatments in a split plot design, and the spacing treatments were randomized within each of five blocks. Spacing treatment plots were $2 \mathrm{~m}$ long in $1.12 \mathrm{~m}$ wide beds, with $1 \mathrm{~m}$ buffer plots between. Spacing treatments were: (1) unthinned (operational average spacing $0.6 \mathrm{~cm}$ ), (2)

\begin{tabular}{|c|c|c|c|c|c|c|}
\hline \multirow[b]{2}{*}{ Species } & \multirow{2}{*}{$\begin{array}{l}\text { Low density } \\
\text { (seedlings.m }{ }^{-2} \text { ) } \\
\text { or spacing in } \\
\text { drill }(\mathrm{cm})\end{array}$} & \multirow[b]{2}{*}{$\begin{array}{c}\text { Years in } \\
\text { forest at } \\
\text { measurement }\end{array}$} & \multicolumn{3}{|c|}{$\begin{array}{l}\text { Increase due to wide } \\
\text { spacing compared with } \\
\text { normal nursery spacing }\end{array}$} & \multirow[b]{2}{*}{ Author } \\
\hline & & & $\begin{array}{c}\text { Survival } \\
\%\end{array}$ & $\begin{array}{l}\text { Total } \\
\text { height } \\
-\%\end{array}$ & $\begin{array}{l}\text { Height } \\
\text { growth } \\
\text { ial - }\end{array}$ & \\
\hline Longleaf pine & 108 & 1 & 19 & & & $\begin{array}{l}\text { Deer } \\
\quad 1955\end{array}$ \\
\hline Slash pine & 108 & 1 & $16^{1}$ & & & $\begin{array}{c}\text { Shoulders } \\
1961\end{array}$ \\
\hline Slash pine & 215 & 2 & 0 & & 20 & $\begin{array}{l}\text { Shipman } \\
1964\end{array}$ \\
\hline Loblolly pine & 108 & 1 & 91 & & & $\begin{array}{c}\text { Shoulders } \\
1961\end{array}$ \\
\hline Loblolly pine & 215 & 2 & 0 & & 29 & $\begin{array}{l}\text { Shipman } \\
1964\end{array}$ \\
\hline Loblolly pine & 161 & 3 & 0 & 25 & & $\begin{array}{l}\text { Switzer and } \\
\text { Nelson } 1963\end{array}$ \\
\hline Monterey pine & 101 & 5 & 2 & 10 & $70^{2}$ & $\begin{array}{l}\text { Benson and } \\
\text { Shepherd } 1976\end{array}$ \\
\hline Monterey pine & $6.4 \mathrm{~cm}$ & 2 & $28^{3}$ & 30 & 33 & $\begin{array}{r}\text { Bowles } \\
1981\end{array}$ \\
\hline Monterey pine & $8.0 \mathrm{~cm}$ & 2 & $7^{3}$ & 23 & 30 & $\begin{array}{r}\text { Bowles } \\
1981\end{array}$ \\
\hline White pine & 161 & 5 & 4 & 0 & & $\begin{array}{l}\text { Mullin and } \\
\quad \text { Bowdery 1977a }\end{array}$ \\
\hline Red pine & 161 & 5 & 7 & 8 & & $\begin{array}{l}\text { Mullin and } \\
\text { Bowdery } 1978\end{array}$ \\
\hline Lodgepole pine & $12 \mathrm{~cm}$ & 2 & 0 & & 92 & $\begin{array}{l}\text { van den } \\
\quad \text { Driessche } 1982\end{array}$ \\
\hline White spruce & 161 & 5 & 0 & 8 & & $\begin{array}{l}\text { Mullin and } \\
\text { Bowdery 1977b }\end{array}$ \\
\hline Sitka spruce & $12 \mathrm{~cm}$ & 3 & 19 & & 63 & $\begin{array}{l}\text { van den } \\
\quad \text { Driessche } 1982\end{array}$ \\
\hline $\begin{array}{l}\text { Coastal Douglas } \\
\text { fir }\end{array}$ & $12 \mathrm{~cm}$ & 3 & 17 & & 36 & $\begin{array}{l}\text { van den } \\
\quad \text { Driessche } 1982\end{array}$ \\
\hline $\begin{array}{l}\text { Interior Douglas } \\
\text { fir }\end{array}$ & $12 \mathrm{~cm}$ & 3 & 16 & & 13 & $\begin{array}{l}\text { van den } \\
\quad \text { Driessche } 1982\end{array}$ \\
\hline
\end{tabular}

1 Dry years only

2Stem volume

3Frosty site 
$2 \mathrm{~cm}$ and (3) $5 \mathrm{~cm}$. Spacing was done by hand in June of the first year after germination was complete. Undercutting was carried out at about $15 \mathrm{~cm}$ below the bed surface during the second year. The treatments were: (1) no undercut, (2) undercut monthly during July to September and (3) monthly during May to September. Fertilization, irrigation and pest control were those normally used in the nursery.

In August of the second year the average number of seedlings per unit length of drill was determined by counting the number of seedlings in two randomly selected $14.3 \mathrm{~cm}$ lengths of each drill in every plot. In October of the second year, 30 seedlings were lifted from each plot, then washed prior to measurement of shoot height, root collar diameter, and shoot and root dry weight. In November of the second year, 50 white spruce trees were lifted from each plot, labelled and placed into storage at $-2^{\circ} \mathrm{C}$. These were planted in rows of 50 trees per treatment, replicated five times in randomized blocks, at Wansa Lake in May, 1981. The planting site is in the sub-boreal spruce forest at $760 \mathrm{~m}$ elevation, about $40 \mathrm{~km}$ southeast of Prince George, in central British Columbia. Partial removal of logging debris with a tractor resulted in a relatively clear site which was mattock planted.

In March, 1981, five Douglas-fir seedlings were lifted from each plot for root growth capacity (RGC) measurements (Burdett 1979). The five trees from each plot were planted in a 4.5-L capacity pot, containing a moist peat and vermiculite mixture, and placed in a growth chamber where day and night temperatures were 30 and $25^{\circ} \mathrm{C}$, light intensity was 400 micro Einsteins $(\mu \mathrm{E}) \cdot \mathrm{m}^{-2} \cdot \mathrm{s}^{-1}$ during a 16 -hour photoperiod and relative humidity was about $75 \%$. Each treatment was represented by five plots which were randomized in the growth chambers. the number of new roots greater than $1.0 \mathrm{~cm}$ were counted on washed root systems after 10 days growth.

In October, 1981, and in October, 1983, survival of white spruce at Wansa Lake was determined for all trees, and the total height, length of new shoot growth and ground level stem diameter was determined for the first 20 live trees in each row.

Only the effects of spacing are reported here. Undercutting treatments had some effects but interacted little or not at all with spacing.

\section{Experiment 2}

In May, 1980, five conifer species were sown at four nurseries (Table 2) with a mechanical precision seeder to obtain six spacings. The seeder was a single drill, unpowered, machine in which plastic cups were selected according to seed size and shape to obtain singling, and spacing was controlled by changing gear ratios. The planned spacings for all species were $0.5,1.2,2.0,4.0,8.0$, and $12 \mathrm{~cm}$. Standard $1.12 \mathrm{~m}$ wide seed beds were sown with seven drills $15 \mathrm{~cm}$ apart, and $7-\mathrm{m}$ lengths of bed were used for spacing treatment plots. Spacing treatments were replicated in three randomized blocks for each species at each nursery. The number of seeds per unit length of drill were determined before covering sand was applied by counting the number of seeds in two randomly selected $14.3-\mathrm{cm}$ length of each drill in every plot. The same procedure was used to determine the density of 1-0 and 2-0 seedlings in August of the first and second year.

Fertilization was the same for all species at all nurseries and totalled $73 \mathrm{~kg} \mathrm{~N}, 72 \mathrm{kgP}$ and $50 \mathrm{~kg} \mathrm{~K} /$ ha during the first year and $193 \mathrm{~kg} \mathrm{~N}, 72 \mathrm{kgP}$ and $50 \mathrm{~kg} \mathrm{~K} / \mathrm{h}$ a during the second year.

In mid-October of the second year (1981) samples of 30 trees were lifted from all plots, washed, and used to determine shoot height, root collar diameter, and shoot and root dry weight. To measure RGC, eight seedlings were lifted from each plot and potted four per 4.5-L pot in March, 1982. Thus each treatment was represented by 24 trees. They were then
Table 2. Species, nurseries sown, and seed origins and germination percents for experiments 2 and 3 .

\begin{tabular}{llll}
\hline & Nursery & Germina- \\
species & Sown & Origin & \begin{tabular}{c} 
tion \% \\
\hline
\end{tabular} \\
\hline
\end{tabular}

\begin{tabular}{llll}
\multicolumn{2}{c}{ Experiment 2 } & \\
Douglas-fir & Koksilah & Nanaimo & 88 \\
Douglas-fir & Campbell River & Nanaimo & 88 \\
Douglas-fir & Surrey & Nanaimo & 88 \\
Douglas-fir & North Road & Nanaimo & 88 \\
Interior Douglas-fir & Surrey & Quesnel & 84 \\
Sitka spruce & Campbell River & Kingcome River & 90 \\
White spruce & Surrey & McGregor River & 77 \\
Western red cedar & Koksilah & Pemberton & 85 \\
& \multicolumn{2}{c}{ Experiment 3 } & \\
& \multicolumn{2}{c}{ Campbell River } & Great Central Lake \\
Douglas-fir & Surrey & Sayward & 81 \\
Douglas-fir & Surrey & Chase & 83 \\
Lodgepole pine & &
\end{tabular}

treated as described in experiment 1, except that Douglas-fir and interior Douglas-fir were kept in the growth chambers for two weeks, but the other species for only one week.

In January, 1982, five trees were sampled in all of the Douglas-fir plots, except the widest spacing $(12 \mathrm{~cm})$, in the North Road nursery for counting needle primordia in the terminal bud and two lateral buds from the uppermost branches. Counting was carried out under a binocular microscope with x30 magnification.

Seventy trees from each Sitka spruce plot were also lifted in March, 1982 and planted in rows at Naka Creek, in the coastal western hemlock forest, at $200 \mathrm{~m}$ elevation, on northeast Vancouver Island. The 70 trees from each replication were pooled and then subdivided to provide 50 trees per treatment for each of four randomized blocks. The site, which was covered by much logging debris and weedy, was planted using a mattock. In September 1983, survival was determined for all trees and total height, new shoot growth and ground level stem diameter were determined by measuring the first 15 live trees per row.

\section{Experiment 3}

In May 1982, Douglas-fir and lodgepole pine (Table 2) were sown with a vacuum drum precision seeder. This tractor mounted machine rototills, forms the bed and then sows seven drills at $15 \mathrm{~cm}$ spacing in one operation. Spacings of $1.9 \mathrm{~cm}, 2.8 \mathrm{~cm}, 5.0 \mathrm{~cm}, 7.4 \mathrm{~cm}$ and $10.6 \mathrm{~cm}$, were tested using 7-m long plots laid out on 1.12-m wide seed beds, and replicated in four randomized blocks. Fertilization, irrigation and pest control were those normally used in the nursery. In August of the first and second years 50 spacings (inter seedling distances) were measured in randomly selected drills in each plot. In October of the second year 30 trees were lifted from each plot, washed, and used to determine shoot height, root collar diameter, and shoot and root dry weight. An additional five trees were lifted from each Douglas-fir plot to provide material for measuring needle areas and dry weights and for estimating the number and total length of branches. Projected needle area was determined for 50 needles sampled from the upper part of the leading shoot of the five trees using a photometric device (Balderston 1972). Dry weight of these needles and an additional 100 needles were determined.

\section{Experiment 4}

Regularity of seed placement was examined in three types of seeders designed to achieve precision seed placement at chosen spacings. The first of these had a mechanical singling system, relying on small plastic cups chosen to fit the seed size and shape, and was used in experiment 2 . The second 
and third machines used a "vacuum" system in which the seeds were held against small holes by air pressure to achieve singling. These differed in that the second machine employed a large drum with rows of holes round it at the drill spacing of $15 \mathrm{~cm}$. Since the holes were also aligned along the drum axis seeds were sown at the same time in each drill so that a rectangular spacing was obtained. This machine had been used in experiment 3 . The third machine had a metal disc turning in a vertical plane with holes near the circumference for picking up and sowing seed. One disc was required for each drill sown. Rectangular spacing would usually not be obtained because the disc carrying modules were unconnected. In all three machines spacing was controlled by choosing suitable gear ratios in a train driven by ground powered wheels.

Seed placement of the first and third machines was examined by operating them in a 5 -m long wooden guide constructed with a wooden channel a little narrower than the wheels (about $5 \mathrm{~cm}$ wide and $1.5 \mathrm{~cm}$ deep) along which adhesive tape was stretched, sticky side up, to prevent the seed from bouncing. Distances between 200 seeds were measured for each spacing setting. Spacings between seeds sown by the second machine were measured in the nursery under operational conditions before seeds were covered with sand. This was necessary because the vacuum drum machine is large and must be powered by a tractor.

\section{Culling}

Culling to different height and diameter standards was conducted on the height and diameter measurements for experiments 1 and 3 . The proportion of seedlings remaining after

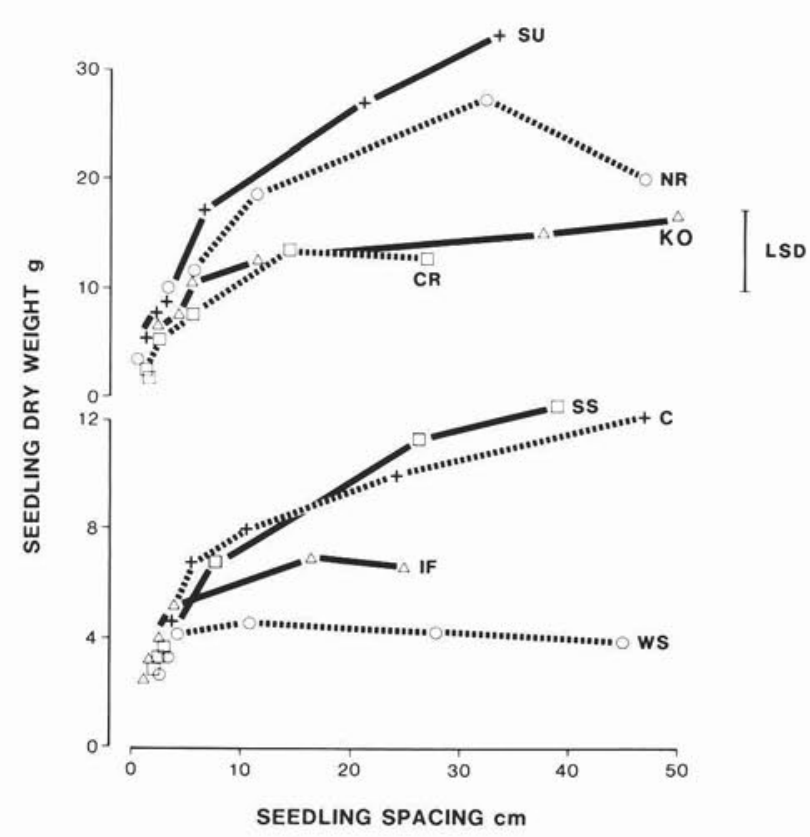

Figure 1. Mean dry weight of 2-0 seedlings in experiment 2 shown by mean spacings between seedlings in August of the second growing season. Upper four curves are all Douglas-fir grown at four nurseries: $\mathrm{SU}=$ Surrey, $\mathrm{NR}=$ North Road, $\mathrm{KO}=$ Koksilah and $\mathrm{CR}=$ Campbell River. Lower four curves represent four species: $S S=$ Sitka spruce,$C=$ western red cedar, IF = interior Douglas-fir and $\mathrm{WS}=$ white spruce. The least significant difference (LSD) is for $p=0.05$ and applies to the four coastal Douglas-fir curves. culling was multiplied by the mean number of seedlings per $\mathrm{m}$ of bed for the particular spacing under consideration. This number was determined from the spacing measurements made during August of the second year.

\section{Statistical Analysis}

All data have been subjected to analysis of variance and, where significance was indicated, means were separated by Duncan's multiple range test. In general, analysis was done on means for treatment plots, but where culling was done and coefficients of variation were calculated individual seedling values were used.

\section{Results}

\section{Seedling Response in the Nursery}

Increase in spacing between seedlings resulted in increase in dry weight and root collar diameter in experiments 1 and 2. Increasing spacing of white spruce from 0.6 to $5 \mathrm{~cm}$ increased two-year old seedling (2-0) dry weight from $3.5 \mathrm{~g}$ to $7.0 \mathrm{~g}$ and root collar diameter from $4 \mathrm{~mm}$ to $5.8 \mathrm{~mm}$. A similar increase in spacing for Douglas-fir increased 2-0 dry weight from $7.6 \mathrm{~g}$ to $14.3 \mathrm{~g}$ and root collar diameter from $5.0 \mathrm{~mm}$ to $6.8 \mathrm{~mm}$. In experiment 2 , increase in these two measurements was essentially linear and rapid up to a spacing of $8-10 \mathrm{~cm}$ (Figs. 1, 2).

At close spacings, where responses were large, a $1-\mathrm{cm}$ increase of within drill spacing increased seedling dry weight by 0.5 to $1.5 \mathrm{~g}$ and root collar diameter by 0.2 to $0.25 \mathrm{~mm}$. Increase in spacing within the drill above about $8-10 \mathrm{~cm}$ resulted in a slower increase in dry weight and root collar

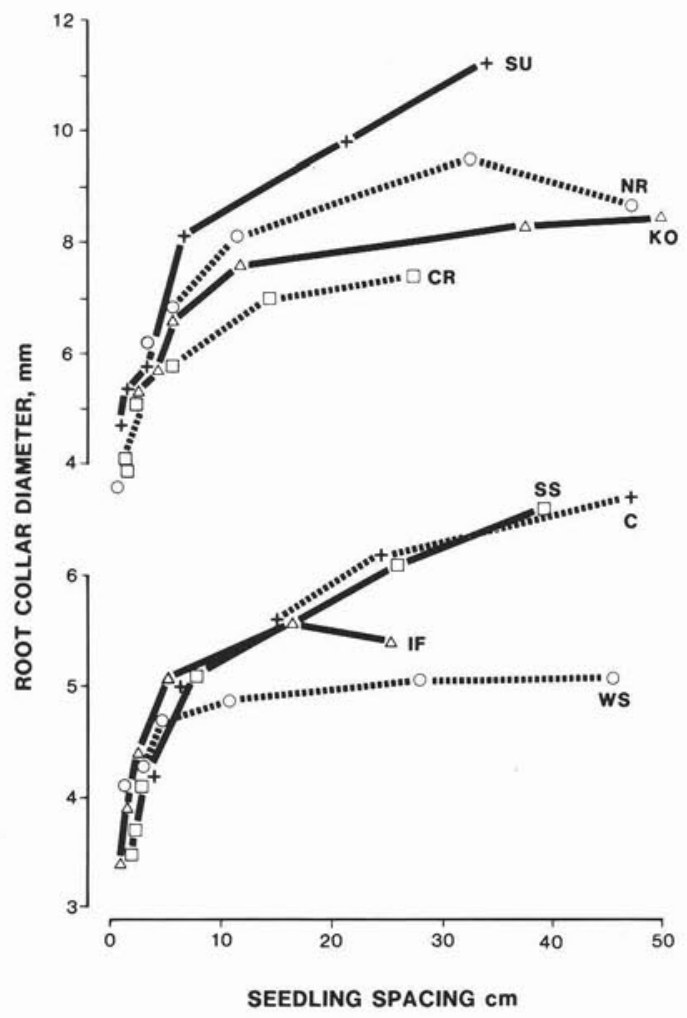

I LSD

Figure 2. Mean root collar diameter of $2-0$ seedlings in experiment 2 shown by mean spacings between seedlings in August of the second growing season. Coding of curves is as for Fig. 1. The least significant difference (LSD) is for $p=0.05$ and applies to the four coastal Douglas-fir curves. 
diameter, and the actual response depended on nursery and species (Figs. 1,2). Faster growing species, which were therefore the largest when lifted as $2-0$ seedlings, benefitted from wider spacings more than slower growing species. The response of the slower growing interior Douglas-fir and white spruce ceased at closer spacings than response of the faster growing coastal Douglas-fir, Sitka spruce and western red cedar (Figs. 1, 2).

Shoot height of most species examined seemed to increase when spacing was increased up to $3-5 \mathrm{~cm}$, but thereafter remained constant, or eventually decreased (Fig. 3). In white spruce the effect of wider spacing was largely to reduce height even at quite close spacings (Table 3 ). Since height either does not increase greatly or else is decreased by wider spacing, but diameter increases or remains constant, wider

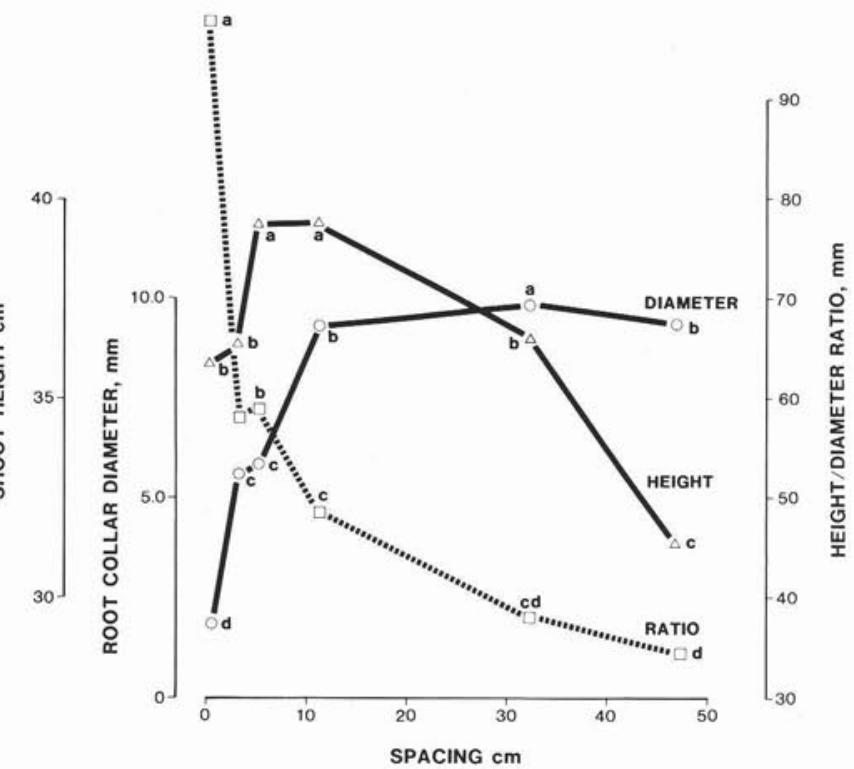

Figure 3. Shoot height, root collar diameter and height/diameter ratio for 2-0 Douglas-fir grown at North Road in experiment 2 shown by spacing between seedlings in August of the second growing season.
Table 3. Shoot height of 2-0 white spruce shown by spacing in the drill for experiments 1 and 2.

\begin{tabular}{ccccc}
\hline \multicolumn{2}{c}{ Experiment 1 } & & \multicolumn{2}{c}{ Experiment 2 } \\
\cline { 5 - 5 } $\begin{array}{c}\text { Spacing } \\
\text { cm }\end{array}$ & $\begin{array}{c}\text { Height } \\
\text { cm }\end{array}$ & & $\begin{array}{c}\text { Spacing } \\
\text { cm }\end{array}$ & $\begin{array}{c}\text { Height } \\
\text { cm }\end{array}$ \\
\hline 0.6 & $23.4 \mathrm{a}^{*}$ & 0.5 & $15.0 \mathrm{a}$ \\
2.0 & $22.6 \mathrm{a}$ & 1.2 & $17.0 \mathrm{ab}$ \\
5.0 & $20.6 \mathrm{~b}$ & 2.0 & $15.5 \mathrm{~b}$ \\
& & 4.0 & $14.7 \mathrm{ac}$ \\
& & 8.0 & $13.7 \mathrm{ac}$ \\
& & 12.0 & $12.9 \mathrm{c}$ \\
\hline
\end{tabular}

"Values within columns followed by the same letter are not significantly different at $p=0.05$

Table 4. Height/diameter ratios $(\mathrm{mm} / \mathrm{mm})$ shown by spacing for different species and nurseries (experiments 1 and 3 ).

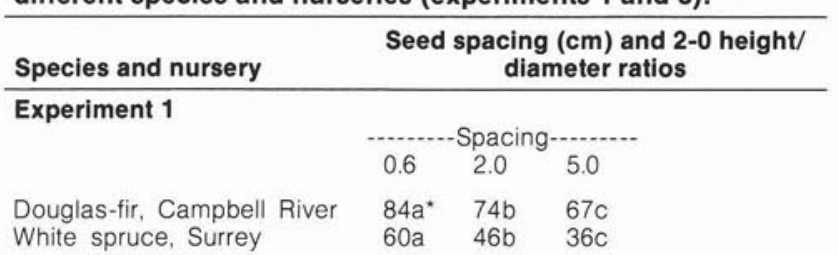

Experiment 2

Douglas-fir, Campbell River

Douglas-fir, Surrey

Lodgepole pine, Surrey

\begin{tabular}{lllll}
1.9 & 2.8 & 5.0 & 7.4 & 10.6 \\
$77 a$ & $70 a b$ & $68 b c$ & $61 c d$ & $56 d$ \\
$84 a$ & $87 a$ & $73 b$ & $66 c$ & $62 c$ \\
$67 a$ & $55 b$ & $52 b c$ & $46 b c$ & $42 c$ \\
\hline
\end{tabular}

"Values on a line followed by the same letter are not significantly different at $p=0.05$

spacing resulted in a relatively continuous decrease in the height: diameter ratio (Fig. 3, Table 4). Wider spacing tended to result in lower shoot/ root dry weight ratios (Table 5).

Spacing has a variety of effects on the development of nursery seedlings. For example, the number of needle primordia in buds of 2-0 Douglas-fir, grown at North Road in experiment 2, increased as spacing increased to $2 \mathrm{~cm}$ (Table 6). Further increase in spacing appeared to gradually reduce the number of needle primordia even though seedling dry weight continued to increase up to 8-cm spacing (Fig. 1). Examination of 2-0 Douglas-fir, grown at Campbell River and Surrey

\begin{tabular}{|c|c|c|c|c|c|c|}
\hline $\begin{array}{l}\text { Species and nursery } \\
\text { Experiment } 1\end{array}$ & \multicolumn{6}{|c|}{ Seed spacing $(\mathrm{cm})$ and shoot/root ratios } \\
\hline & 0.6 & 2.0 & 5.0 & & & \\
\hline $\begin{array}{l}\text { Douglas-fir, Campbell River } \\
\text { White spruce, Surrey }\end{array}$ & $\begin{array}{l}2.5 \mathrm{a}^{\star} \\
2.6 \mathrm{a}\end{array}$ & $\begin{array}{l}2.3 b \\
1.9 b\end{array}$ & $\begin{array}{l}2.2 b \\
1.5 c\end{array}$ & & & \\
\hline \multicolumn{7}{|l|}{ Experiment 2} \\
\hline & 0.5 & 1.2 & 2.0 & 4.0 & 8.0 & 12.0 \\
\hline $\begin{array}{l}\text { Douglas-fir, Campbell River } \\
\text { Douglas-fir, Koksilah } \\
\text { Douglas-fir, Surrey } \\
\text { Douglas-fir, North Road } \\
\text { Interior Douglas-fir, Surrey } \\
\text { Sitka spruce, Campbell River } \\
\text { White spruce, Surrey } \\
\text { Western red cedar, Koksilah }\end{array}$ & $\begin{array}{l}2.6 \mathrm{a} \\
1.6 \mathrm{a} \\
3.5 \mathrm{a} \\
3.9 \mathrm{a} \\
1.8 \mathrm{a} \\
2.4 \mathrm{a} \\
1.5 \mathrm{ab} \\
4.8 \mathrm{a}\end{array}$ & $\begin{array}{l}1.4 a \\
2.0 a \\
3.5 a \\
2.9 a b \\
1.8 a \\
2.8 a \\
1.7 a \\
4.0 a\end{array}$ & $\begin{array}{l}3.3 \mathrm{a} \\
1.6 \mathrm{a} \\
2.9 \mathrm{a} \\
2.6 \mathrm{abc} \\
1.7 \mathrm{a} \\
2.6 \mathrm{a} \\
1.4 \mathrm{bc} \\
3.6 \mathrm{a}\end{array}$ & $\begin{array}{l}2.4 a \\
2.1 \mathrm{a} \\
2.9 \mathrm{a} \\
2.4 \mathrm{bc} \\
1.6 \mathrm{a} \\
1.7 \mathrm{~b} \\
1.3 \mathrm{c} \\
3.6 \mathrm{a}\end{array}$ & $\begin{array}{l}2.4 \mathrm{a} \\
1.7 \mathrm{a} \\
2.6 \mathrm{a} \\
2.1 \mathrm{c} \\
1.6 \mathrm{a} \\
1.6 \mathrm{~b} \\
1.3 \mathrm{~b} \\
3.8 \mathrm{a}\end{array}$ & $\begin{array}{l}1.8 \mathrm{a} \\
2.0 \mathrm{a} \\
2.3 \mathrm{a} \\
2.0 \mathrm{bc} \\
1.4 \mathrm{a} \\
1.6 \mathrm{~b} \\
1.3 \mathrm{c} \\
4.0 \mathrm{a}\end{array}$ \\
\hline
\end{tabular}

-Values on a line followed by the same letter are not significantly different at $p=0.05$ 
Table 6. Number of needle primordia in terminal bud and two uppermost lateral buds in 2-0 Douglas-fir grown at different spacings in North Road nursery (experiment 2).

\begin{tabular}{ccc}
\hline Spacing, $\mathbf{c m}$ & Terminal bud & Lateral buds \\
\hline 0.5 & $237 \mathrm{a}^{*}$ & $182 \mathrm{a}$ \\
1.2 & $278 \mathrm{ab}$ & $205 \mathrm{ab}$ \\
2.0 & $346 \mathrm{~b}$ & $260 \mathrm{~b}$ \\
4.0 & $318 \mathrm{~b}$ & $252 \mathrm{~b}$ \\
8.0 & $288 \mathrm{ab}$ & $240 \mathrm{~b}$ \\
\hline
\end{tabular}

-Values in a column followed by the same letter are not significantly different at $p=0.05$

nurseries in experiment 3 , showed that the number of both first and second order branches increased with wider spacing (Table 7). The number of second order branches rose from one or two per seedling at close spacing to 12 to 18 at wider spacing. Mean branch length showed an increasing trend with wider spacing, although significant differences were not demonstrated, but the substantial increase in total first order branch length per tree associated with wider spacing was primarily due to the increased number of first order branches.

At Campbell River, mean needle dry weight and projected area increased as spacing increased, but area per unit weight of needle decreased (Table 7). At Surrey nursery the trends in needle dry weight and area per unit dry weight were the same, but not so pronounced, and needle area showed no significant effect of spacing. These observations suggest that 2-0 Douglas-fir seedlings grown at close spacing tend to develop shade type needles, that is needles with relatively large area per unit dry weight, whereas those at wide spacing develop sun type needles, that is needles with relatively small area per unit dry weight.

Measurements of RGC made on Douglas-fir grown at four nurseries showed modest increases up to $2 \mathrm{~cm}$ spacing at two nurseries and no significant differences at the other two nurseries (Table 8). In interior Douglas-fir higher RGC values were obtained at some spacings above $0.5 \mathrm{~cm}$, but not all. In Sitka spruce and western red cedar RGC tended to increase steadily with wider spacing, while RGC was unaffected by spacing in white spruce.

\section{Spacing}

Measurements of spacings between seeds, in experiment 4 , showed that machine 1, the mechanical seeder, produced a wide spread of spacings, particularly when set to sow at 4 - and 8-cm spacing (Fig. 4). A well defined mode was evident with the mechanical seeder only at the $2-\mathrm{cm}$ spacing, and this was in the $0-0.5 \mathrm{~cm}$ class, indicating a large number of doubles. The vacuum machines both showed a greater concentration

Table 7. Branch numbers and lengths, and needle dry weights and projected areas for 2-0 Douglas-fir grown at five spacings in two nurseries (experiment 3 ).

\begin{tabular}{|c|c|c|c|c|c|c|c|}
\hline Spacing & $\begin{array}{c}\text { Number of } \\
\text { 1st order } \\
\text { branches } \\
\text { per tree }\end{array}$ & $\begin{array}{l}\text { Total } \\
\text { length of } \\
\text { all 1st } \\
\text { order } \\
\text { branches } \\
\text { per tree } \\
\text { cm }\end{array}$ & $\begin{array}{c}\text { Mean } \\
\text { length of } \\
\text { 1st order } \\
\text { branches } \\
\mathrm{cm}\end{array}$ & $\begin{array}{c}\text { Number of } \\
\text { 2nd order } \\
\text { branches } \\
\text { per tree }\end{array}$ & $\begin{array}{c}\text { Needle } \\
\text { dry } \\
\text { weight } \\
\text { mg }\end{array}$ & $\begin{array}{c}\text { Projected } \\
\text { area of } \\
50 \\
\text { needles } \\
\mathrm{cm}^{2}\end{array}$ & $\begin{array}{c}\text { Projected } \\
\text { area per } \\
\text { unit } \\
\text { weight } \\
\text { of needle } \\
\mathbf{c m}^{2} \mathbf{g}^{-1}\end{array}$ \\
\hline \multicolumn{8}{|c|}{ Campbell River nursery } \\
\hline \begin{tabular}{r|}
1.9 \\
2.8 \\
5.0 \\
7.4 \\
10.6
\end{tabular} & $\begin{array}{l}18.1 a^{*} \\
17.6 a \\
20.2 a b \\
22.8 b \\
23.0 b\end{array}$ & $\begin{array}{l}124 a \\
139 a b \\
181 a b \\
214 c \\
206 b c\end{array}$ & $\begin{array}{l}6.8 a \\
7.9 a \\
8.9 a \\
9.3 a \\
9.0 a\end{array}$ & $\begin{array}{c}1.6 a \\
2.4 a \\
4.6 a \\
12.6 b \\
7.3 a b\end{array}$ & $\begin{array}{r}6.3 a \\
6.9 a \\
8.2 b \\
9.3 c \\
10.4 d\end{array}$ & $\begin{array}{l}22.1 a \\
22.3 a \\
25.2 b \\
26.4 b \\
30.0 c\end{array}$ & $\begin{array}{l}69.9 a \\
65.6 a b \\
61.0 b \\
61.7 b \\
54.4 c\end{array}$ \\
\hline \multicolumn{8}{|c|}{ Surrey nursery } \\
\hline \begin{tabular}{r|}
1.9 \\
2.8 \\
5.0 \\
7.4 \\
10.6
\end{tabular} & $\begin{array}{l}16.2 a \\
20.1 a b \\
23.6 b \\
22.9 b \\
23.0 b\end{array}$ & $\begin{array}{l}156.2 a \\
183.3 b \\
254.9 c \\
238.3 b c \\
268.0 c\end{array}$ & $\begin{array}{r}9.6 a \\
9.3 a \\
10.8 a \\
10.4 a \\
11.7 a\end{array}$ & $\begin{array}{r}2.4 a \\
3.9 a \\
12.5 b \\
13.9 b \\
18.5 b\end{array}$ & $\begin{array}{l}6.9 a \\
7.7 a b \\
7.9 a b \\
8.7 b \\
8.6 b\end{array}$ & $\begin{array}{l}24.2 a \\
24.9 a \\
25.0 a \\
26.3 a \\
26.4 a\end{array}$ & $\begin{array}{l}68.2 a \\
62.8 b \\
61.7 b \\
60.4 b \\
52.2 b\end{array}$ \\
\hline
\end{tabular}

*Values in a column, within each nursery, followed by the same letter are not significantly different at $p=0.05$

Table 8. Root growth capacities shown by spacings in the drill for several species at different nurseries.

\begin{tabular}{|c|c|c|c|c|c|c|}
\hline \multirow[t]{2}{*}{ Species and nursery } & \multicolumn{6}{|c|}{ Spacing $(\mathrm{cm})$ and root growth capacity (new roots $>1 \mathrm{~cm}$ ) } \\
\hline & & -Spacing & 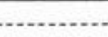 & & & \\
\hline & 0.6 & 2.0 & 5.0 & & & \\
\hline \multirow[t]{2}{*}{ Douglas-fir, Campbell River } & $1.7 a^{\star}$ & $4.1 \mathrm{~b}$ & $4.6 b$ & & & \\
\hline & 0.5 & 1.2 & 2.0 & 4.0 & 8.0 & 12.0 \\
\hline Douglas-fir, Campbell River & $9.1 \mathrm{ab}$ & $8.4 \mathrm{a}$ & $24.3 c$ & $14.5 \mathrm{ab}$ & $16.2 b$ & $13.1 \mathrm{ab}$ \\
\hline Douglas-fir, Koksilah & $15.1 \mathrm{a}$ & $14.1 \mathrm{a}$ & $13.3 a$ & $7.6 a$ & $12.3 a$ & $11.1 \mathrm{a}$ \\
\hline Douglas-fir, Surrey & $28.1 \mathrm{a}$ & $24.1 \mathrm{a}$ & $26.6 a$ & $20.7 a$ & $27.7 a$ & $38.0 \mathrm{a}$ \\
\hline Douglas-fir, North Road & $15.0 \mathrm{ab}$ & $11.4 \mathrm{a}$ & $24.8 \mathrm{c}$ & $12.0 \mathrm{a}$ & $15.0 \mathrm{ab}$ & $21.5 b c$ \\
\hline Interior Douglas-fir, Surrey & $10.6 a$ & $26.5 c$ & $23.0 \mathrm{bc}$ & $14.2 \mathrm{ab}$ & $24.1 \mathrm{bc}$ & 20.0abc \\
\hline Sitka spruce, Campbell River & $8.1 \mathrm{a}$ & $7.8 \mathrm{a}$ & $17.5 \mathrm{ab}$ & $17.3 \mathrm{ab}$ & $30.9 \mathrm{c}$ & $27.0 \mathrm{bc}$ \\
\hline White spruce, Surrey & $1.0 \mathrm{a}$ & $1.7 \mathrm{a}$ & $0.8 \mathrm{a}$ & $0.7 a$ & $0.7 \mathrm{a}$ & $1.4 \mathrm{a}$ \\
\hline Western red cedar, Koksilah & $55.0 \mathrm{a}$ & $69.4 \mathrm{ab}$ & $78.3 \mathrm{ab}$ & $98.0 b$ & $84.3 a b$ & $92.6 \mathrm{~b}$ \\
\hline
\end{tabular}

"Values on a line followed by the same letter are not significantly different at $p=0.05$ 


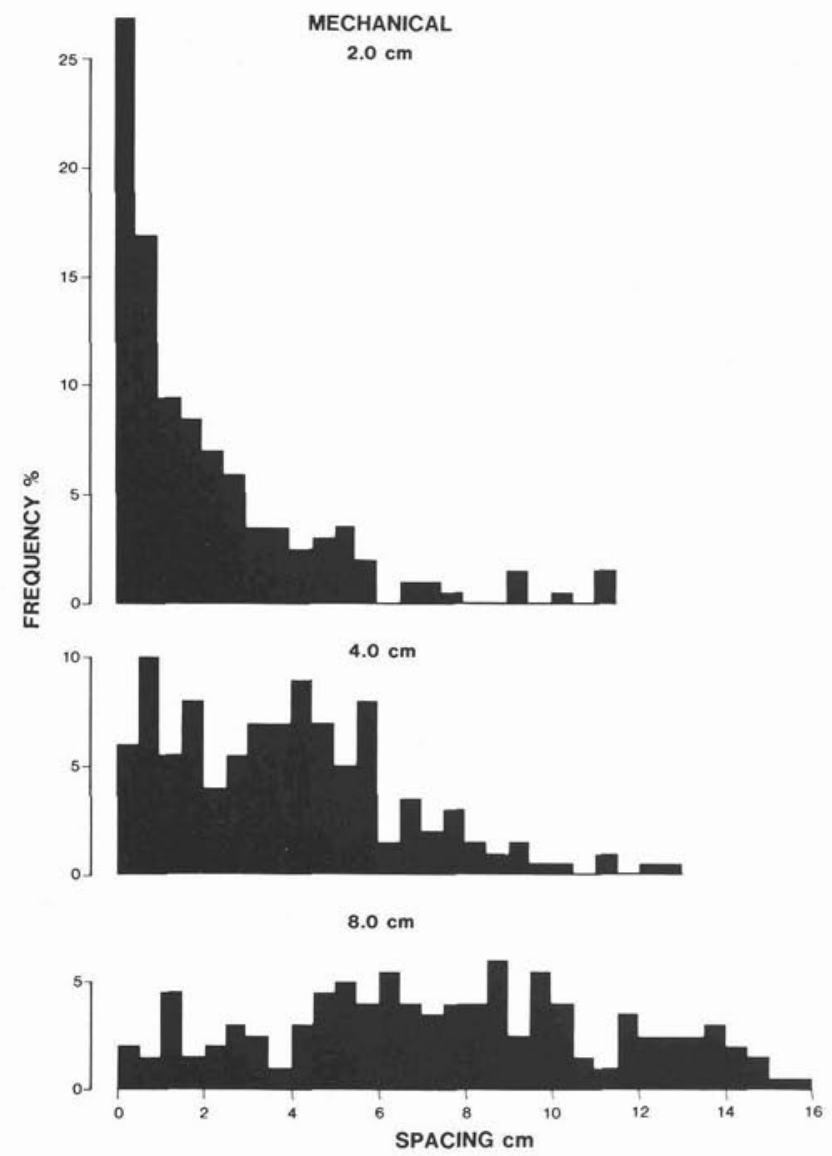

Figure 4. Percent frequency distribution, by $0.5 \mathrm{~cm}$ spacing classes, for distances between 200 Douglas-fir seeds sown with the mechanical seeder set to achieve three spacings: $2.0,4.0$ and $8.0 \mathrm{~cm}$ (experiment 4).

of spacings and a mode close to the intended spacing (Fig. 5), but no more than $65 \%$ of the seed was within $\pm 1 \mathrm{~cm}$ of the intended spacing, and a significant number of doubles occurred. Performance of all three machines was partly dependent on the operator's skill. Choice of cup size, to match the seed, and ground speed affected performance of the mechanical seeder. Amount of vacuum, setting of seed rakes and, to a lesser extent, size of drum or disc hole affected performance of the vacuum machines. More nearly spherical seeds, such as white spruce, were sown more satisfactorily than irregularly shaped seeds such as Douglas-fir.

Four months after sowing, spacing was less variable between Douglas-fir sown with the vacuum drum machine, in experiment 3 , than spacing between seedlings sown with the modified cereal drill (Table 9). At Campbell River nursery the coefficient of variation (CV) was the same in the $7.4-\mathrm{cm}$ spacing treatment with the vacuum seeder as with the cereal seeder. However, at comparable spacings, the vacuum seeder gave more uniform spacing. Uniformity of spacing in first year (1-0) seedlings is affected by the viability of precision spaced seeds. Much of the variation in spacing between precision sown 1-0 seedlings may be attributable to seed with only $81-83 \%$ germination (Table 9 ).

Average spacing cannot be varied much with the modified cereal seeder, whereas precision seeders can be set to achieve a range of spacings. Modal values for spacing of 1-0 Douglas-fir, sown with the cereal seeder, were in the $0-1 \mathrm{~cm}$

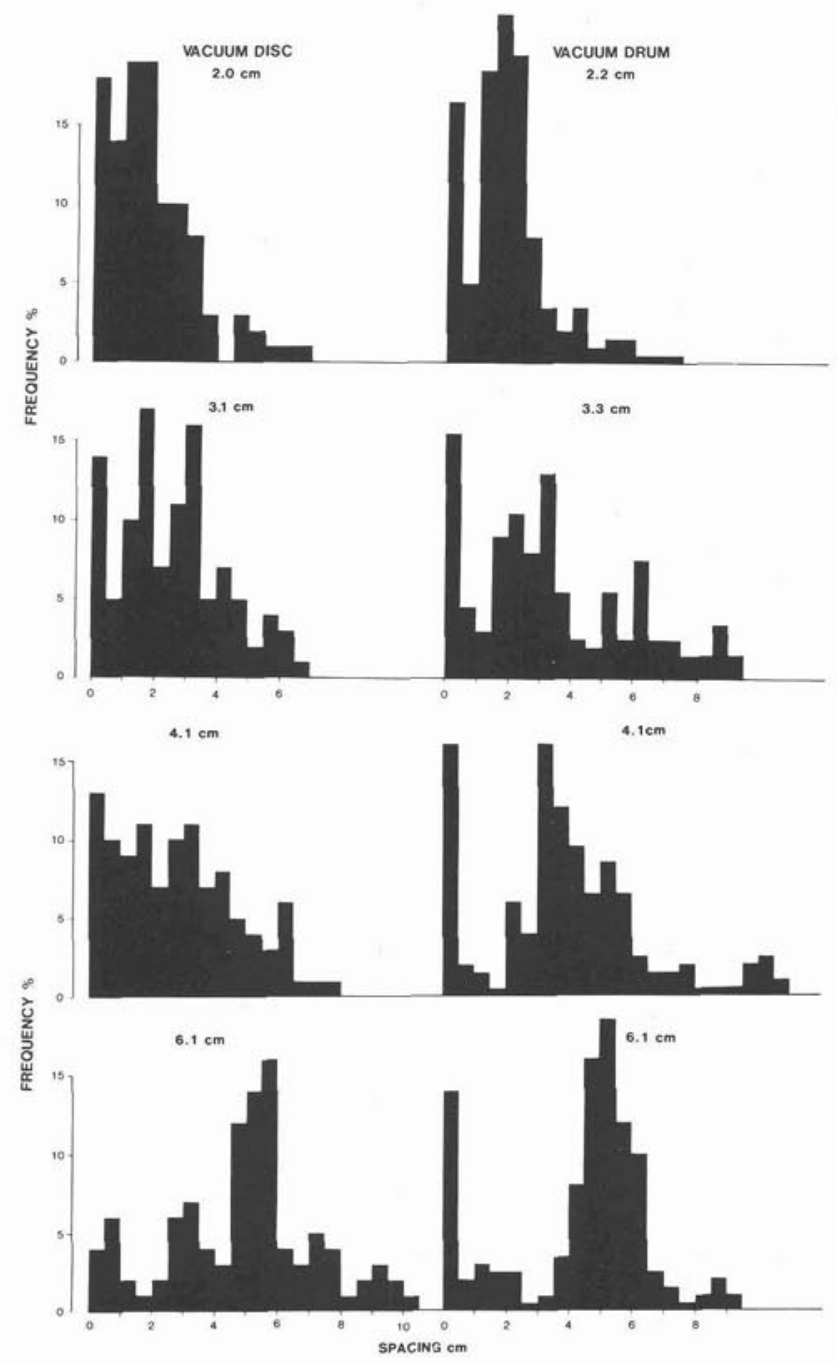

Figure 5. Percent frequency distribution, by $0.5 \mathrm{~cm}$ spacing classes, for distances between 200 Douglas-fir seeds sown with two vacuum precision seeders set to achieve four spacings ranging from $2.0 \mathrm{~cm}$ for the disc seeder to $2.2 \mathrm{~cm}$ for the drum seeder to $6.1 \mathrm{~cm}$ (experiment 4).

Table 9. Spacings, seed germination and coefficient of variation for spacings in 1-0 Douglas-fir during August, shown by two types of seeder (experiment 3).

\begin{tabular}{lcccc}
\hline $\begin{array}{c}\text { Nursery and } \\
\text { seeding machine }\end{array}$ & $\begin{array}{c}\text { Planned } \\
\text { spacing } \\
\text { cm }\end{array}$ & $\begin{array}{c}\text { Measured } \\
\text { spacing } \\
\text { cm }\end{array}$ & $\begin{array}{c}\text { Seed } \\
\text { germina- } \\
\text { tion } \\
\%\end{array}$ & $\begin{array}{c}\text { Coefficient } \\
\text { of variation } \\
\text { for spacing } \\
\%\end{array}$ \\
\hline Surrey nursery & 1.9 & 2.4 & 83 & 80 \\
Vacuum drum & 2.8 & 3.3 & 83 & 91 \\
& 5.0 & 5.1 & 83 & 67 \\
& 7.4 & 7.4 & 83 & 67 \\
& 10.6 & 11.2 & 83 & 83 \\
Modified cereal & - & 1.2 & 82 & 112 \\
seeder & - & 1.5 & 94 & 121 \\
Campbell River nursery & & & & \\
Vacuum Drum & 1.9 & 3.2 & 81 & 75 \\
& 2.8 & 5.9 & 81 & 85 \\
& 5.0 & 6.8 & 81 & 94 \\
& 7.4 & 11.3 & 81 & 105 \\
& 10.6 & 13.7 & 81 & 95 \\
Modified cereal & - & 2.7 & 88 & 105 \\
seeder & - & 2.8 & 77 & 111 \\
\hline
\end{tabular}


MODIFIED CEREAL SEEDER

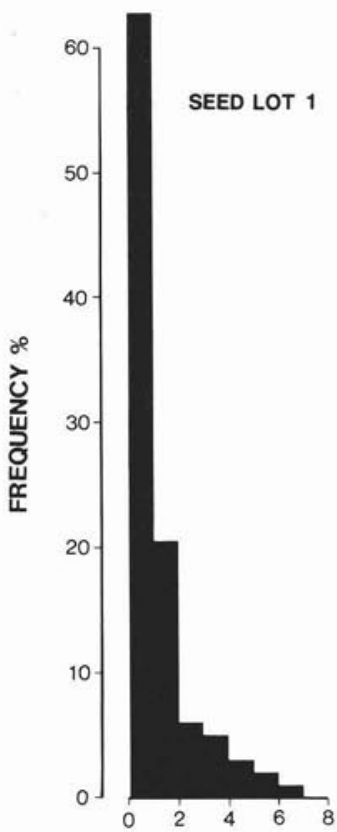

SEED LOT 2

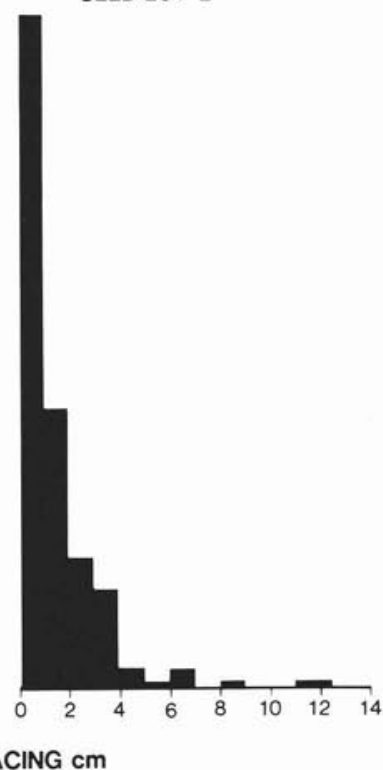

Figure 6. Percent frequency distribution, by $1.0 \mathrm{~cm}$ spacing classes, for distances between 200 one-year old (1-0) Douglas-fir seedlings in two seed lots sown with the modified cereal drill (experiment 3 ).

frequency (Fig. 6), but modal values obtained with the vacuum drum seeder varied between 1 and $10 \mathrm{cms}$ according to the settings used (Fig. 7). Spacings of $0-10 \mathrm{~mm}$ were quite frequent at all settings because of the machine's tendency to sow two seeds per spot. Spacing in the same Douglas-fir beds at the 2-0 stage showed that the modal values were smaller and spacing less precise. Presumably this was accounted for by overwinter mortality. Mean spacing in these beds actually increased by between 35-70\% (Table 10) between August of year 1 and August of year 2. Thus, even if seeds of high germination value were sown precisely, mortality would probably cause uneven spacing between $2-0$ seedlings.

\section{Yields}

The total seedlings produced per unit area of nursery bed decreased as the spacing between seedlings increases. The maximum yield of acceptable seedlings will be obtained from close spacing if the culling standards are low. With current operational height and diameter culling values, spacings as close as $0.6 \mathrm{~cm}$ produced the largest number of acceptable seedlings (Table 11). Increasing the diameter culling value in Douglas-fir from $3.5 \mathrm{~mm}$ to $6.0 \mathrm{~mm}$ reduced yields and made the yields from different spacings at Campbell River closely similar or, in the third experiment, resulted in greatest yield at $5.0 \mathrm{~cm}$ spacing. At Surrey yield of 6 - $\mathrm{mm}$-diameter Douglas-fir seedlings was still greatest at the closest spacing. Increasing culling values to $30 \mathrm{~cm}$ height and $8.0 \mathrm{~mm}$ diameter further decreased yield, but resulted in $5.0-10.6 \mathrm{~cm}$ spacings having highest yields of acceptable seedlings. An increase in culling diameter from 3.5 to $5.0 \mathrm{~mm}$ for lodgepole pine resulted in greatest yield at $2.8 \mathrm{~cm}$ spacing. Regardless of which culling level was used, yield was not significantly improved by wider spacing in white spruce.

\section{Outplanting}

Two-year old white spruce seedlings (from experiment 1)
VACUUM DRUM

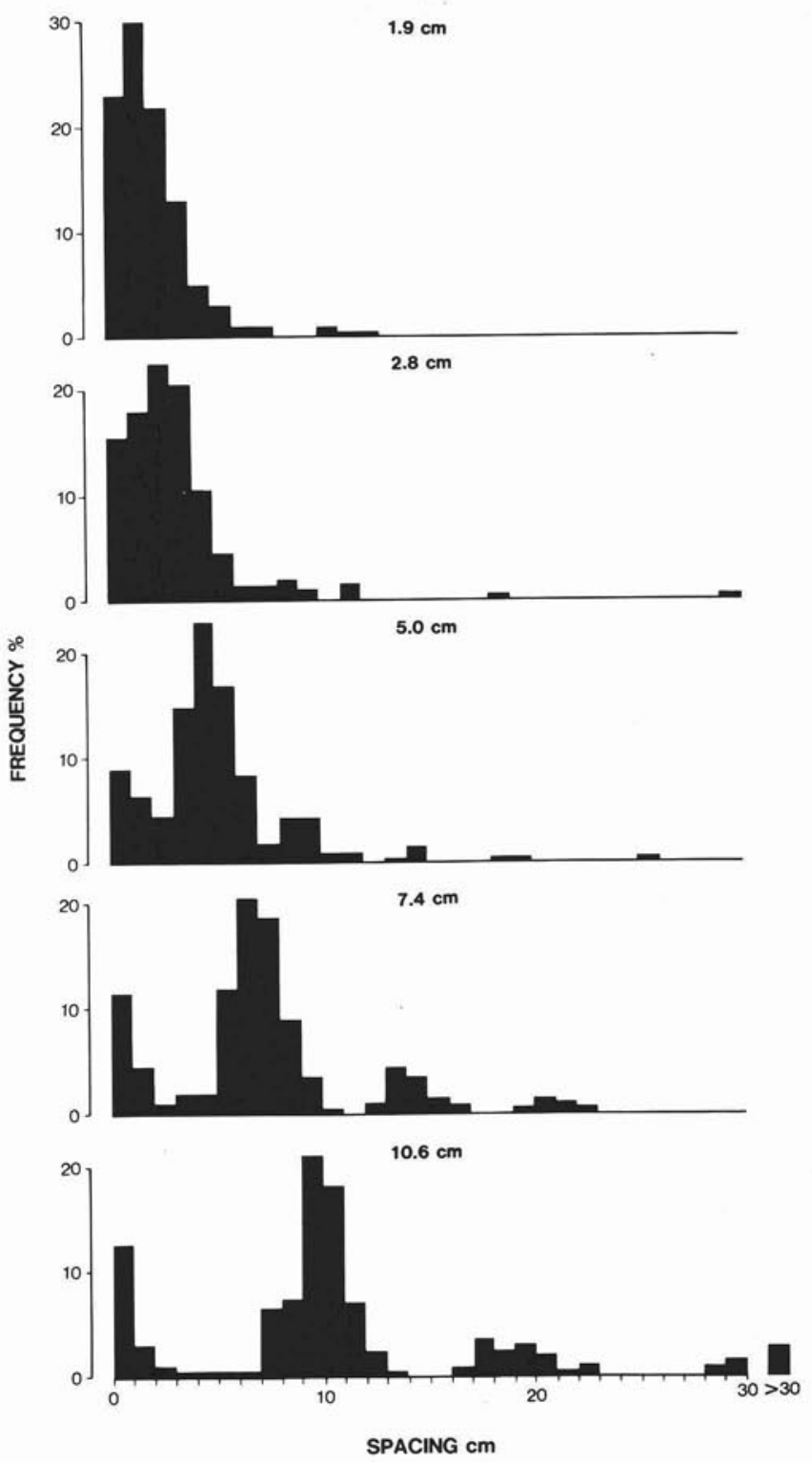

Figure 7. Percent frequency distribution, by $1.0 \mathrm{~cm}$ spacing classes, for distances between one-year old (1-0) Douglas-fir seedlings. The seedlings were sown with the vacuum drum seeder set to achieve five spacings: $1.9,2.8,5.0,7.4$ and $10.6 \mathrm{~cm}$ (experiment 3).

Table 10. Spacings in August of first and second year, and percent increase in spacing for Douglas-fir sown with the vacuum drum seeder at five spacings (experiment 3 ).

\begin{tabular}{lccc}
\hline $\begin{array}{l}\text { Precision } \\
\text { seeder } \\
\text { setting } \\
\text { cm }\end{array}$ & $\begin{array}{c}\text { Mean } \\
\text { spacing } \\
\text { in 1-0 } \\
\text { cm }\end{array}$ & $\begin{array}{c}\text { Mean } \\
\text { spacing } \\
\text { in } \mathbf{2 - 0} \\
\text { cm }\end{array}$ & $\begin{array}{c}\text { Increase in } \\
\text { spacing } \\
\text { August to } \\
\text { August } \\
\%\end{array}$ \\
\hline 1.9 & $2.39 a^{*}$ & $4.07 a$ & 70 \\
2.8 & $3.31 \mathrm{a}$ & $4.93 \mathrm{a}$ & 48 \\
5.0 & $5.12 \mathrm{~b}$ & $7.09 \mathrm{~b}$ & 39 \\
7.4 & $7.38 \mathrm{c}$ & $10.72 \mathrm{c}$ & 45 \\
10.6 & $11.24 \mathrm{~d}$ & $15.04 \mathrm{~d}$ & 34 \\
\hline
\end{tabular}

"Values in a column followed by the same letter are not significantly different at $p=0.05$ 
Table 11. Yield of 2-0 seedlings shown by culling level and spacing in the seedbed (experiments 1 and 3 ).

\section{Culling values}

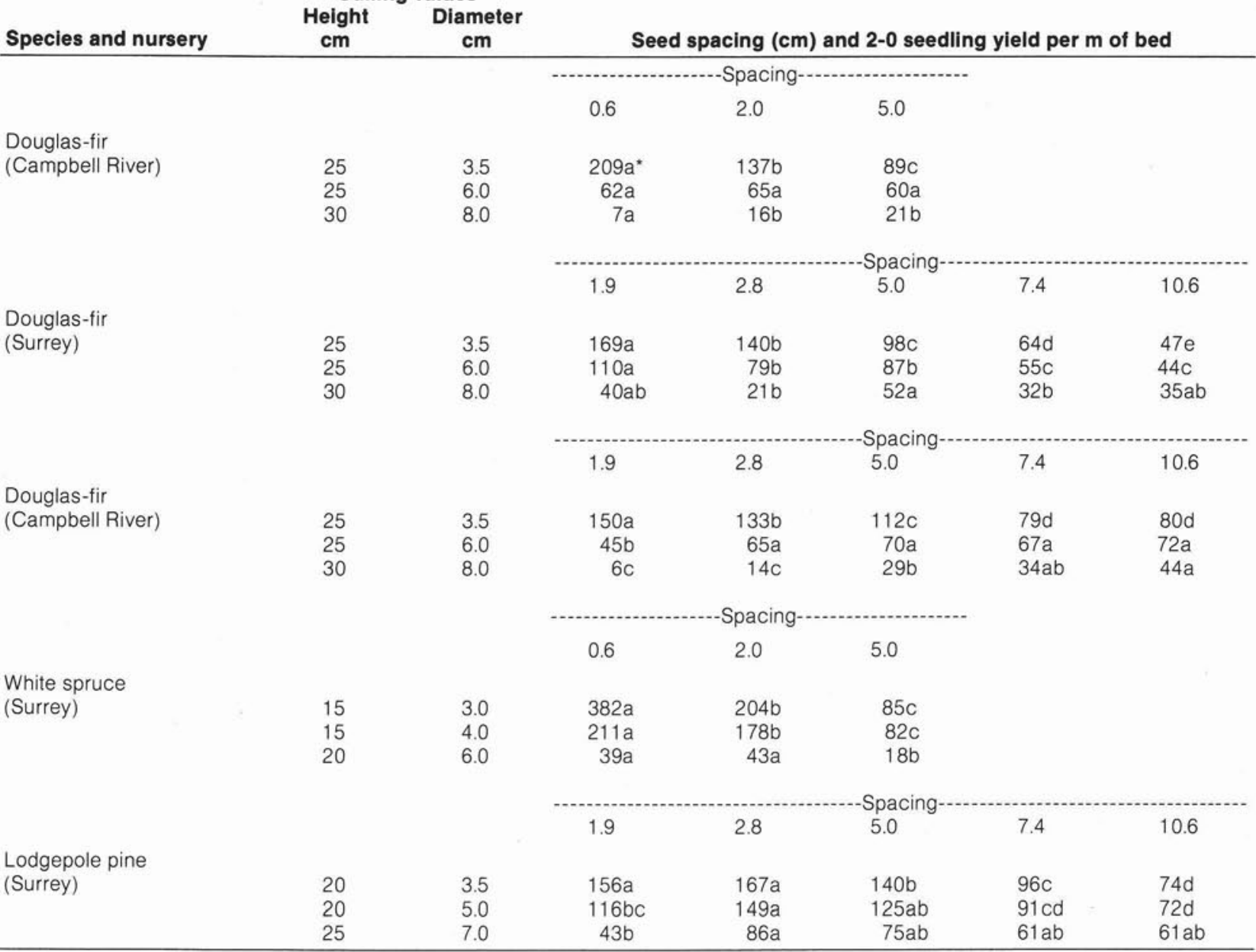

Values on a line followed by the same letter are not significantly different at $p=0.05$

Table 12. Effect of nursery spacing treatment on final nursery spacing and outplanting performance of white spruce (experiment 1 ) and Sitka spruce (experiment 2).

\begin{tabular}{|c|c|c|c|c|c|c|c|}
\hline \multicolumn{2}{|c|}{ Nursery } & \multicolumn{6}{|c|}{ Outplanting } \\
\hline & & \multicolumn{6}{|c|}{ White spruce } \\
\hline \multirow[b]{2}{*}{$\begin{array}{l}\text { Spacing } \\
\text { treatment }\end{array}$} & \multirow{2}{*}{$\begin{array}{c}\text { Spacing } \\
\text { in August } \\
\text { of } 2-0 \mathrm{yr} \\
\mathrm{cm}\end{array}$} & \multicolumn{2}{|c|}{ Year 1} & \multicolumn{4}{|c|}{ Year 3} \\
\hline & & $\underset{\%}{\text { Survival }}$ & $\begin{array}{c}\text { New shoot } \\
\text { growth } \\
\text { cm }\end{array}$ & $\begin{array}{c}\text { Survival } \\
\%\end{array}$ & $\begin{array}{c}\text { Stem dia } \\
\text { mm }\end{array}$ & $\begin{array}{c}\text { New shoot } \\
\text { growth } \\
\text { cm }\end{array}$ & $\begin{array}{c}\text { Total } \\
\text { height } \\
\text { cm }\end{array}$ \\
\hline $0.6 \mathrm{~cm}$ & 1.4 & $91 \mathrm{a}^{*}$ & $6.3 a$ & $80 a$ & $7.1 \mathrm{a}$ & $10.0 \mathrm{a}$ & $38.8 a$ \\
\hline $2.0 \mathrm{~cm}$ & 2.8 & $93 a$ & $7.5 b$ & $84 a$ & $8.5 b$ & $10.9 a$ & $42.2 b$ \\
\hline $5.0 \mathrm{~cm}$ & 4.8 & $94 a$ & $9.0 \mathrm{c}$ & $91 \mathrm{~b}$ & $9.4 c$ & $10.3 a$ & $42.8 b$ \\
\hline \multicolumn{8}{|c|}{ Sitka spruce } \\
\hline & & \multicolumn{6}{|c|}{ year 2} \\
\hline & & & $\underset{\%}{\text { Survival }}$ & \multicolumn{2}{|c|}{$\begin{array}{c}\text { Stem diameter } \\
\mathrm{mm}\end{array}$} & \multicolumn{2}{|c|}{$\begin{array}{c}\text { Total height } \\
\text { cm }\end{array}$} \\
\hline Unspaced & 1.7 & & $83 a^{*}$ & \multicolumn{2}{|c|}{$7.5 a$} & \multicolumn{2}{|c|}{$48.0 \mathrm{a}$} \\
\hline $1.2 \mathrm{~cm}$ & 1.8 & & $91 \mathrm{ab}$ & \multirow{2}{*}{\multicolumn{2}{|c|}{$\begin{array}{l}7.1 \mathrm{a} \\
8.2 \mathrm{ab}\end{array}$}} & \multicolumn{2}{|c|}{$46.9 a$} \\
\hline $2.0 \mathrm{~cm}$ & 3.0 & & $87 a$ & & & \multicolumn{2}{|c|}{$48.2 \mathrm{a}$} \\
\hline $4.0 \mathrm{~cm}$ & 7.9 & & $94 a b$ & \multicolumn{2}{|c|}{$9.0 \mathrm{~b}$} & \multicolumn{2}{|c|}{$54.4 \mathrm{ab}$} \\
\hline $8.0 \mathrm{~cm}$ & 26.3 & & $97 b$ & \multicolumn{2}{|c|}{$11.2 \mathrm{c}$} & \multicolumn{2}{|c|}{$60.4 b$} \\
\hline $12.0 \mathrm{~cm}$ & 38.5 & & $96 b$ & \multicolumn{2}{|c|}{$10.5 \mathrm{c}$} & \multicolumn{2}{|c|}{$61.9 b$} \\
\hline
\end{tabular}

-Within species, values in columns followed by the same letter are not significantly different at $p=0.05$. 
grown at $5 \mathrm{~cm}$ spacing showed greater shoot growth in the year after planting than seedlings grown at $0.6 \mathrm{~cm}$ spacing in the drill (Table 12). Survival of wide spaced seedlings was $11 \%$ greater than that of close spaced seedlings after three years in the forest, and both stem diameter and total height increased with wider spacing.

Sitka spruce was sown to achieve six different spacings in experiment 2, but due partly to poor machine operation and partly to frost heaving, the average spacings became large at the two widest spacing treatments during the second growing season (Table 12). Nevertheless outplanting on a forest site with considerable debris and competing vegetation showed that survival, stem diameter and height of wide spaced trees was greater than that of close spaced trees after two years.

\section{Discussion}

Larger trees usually grow more than smaller trees and much of the greater growth after planting observed in trees that were grown at wide spacing in the nursery can be attributed to larger size (van den Driessche 1984). The question is whether there are other differences in wide spaced stock that might contribute to more survival and growth after planting. Evidently some increase in spacing results in an increase of needle primordia within the bud. More needle primordia could result in greater photosynthetic surface and therefore growth during the year after lifting from the nursery. The possession of more sun type needles by trees from wider spacing may mean that they are better adapted to the light conditions of the planting site. Even if shading by weed competition eventually occurs, newly planted trees are usually fully exposed for several weeks. It might well be an advantage to have needles at least partly adapted to such conditions.

Root growth capacity increased only modestly if at all with wider spacing. The increases in RGC observed were in the order of 2- to 3-fold and could have been accounted for by the 3- to 4-fold increases in root dry mass which were also associated with increase in spacing in these experiments. New root growth was also approximately doubled, and root dry weight increased by increasing spacing of Pinus radiata from 4 to $8 \mathrm{~cm}$ (Balneaves 1983). Larger root systems could be expected to produce proportionally more new roots under RGC test conditions, and the relatively small increases in RGC due to wider spacing probably did not indicate physiological differences in ability to produce new roots. Root growth capacity differences associated with differences in field performance are usually larger (Burdett et al. 1983, van den Driessche 1983) and are probably owing to physiological differences. Thus the small increases in RGC that may result from wider spacing are not likely to have a major effect on outplanting performance.

The proportion of dry matter allocated to the root system, expressed in terms of shoot:root ratio, has traditionally been considered important. Wider spacing usually results in relatively more dry matter being allocated to the root system, i.e. a smaller shoot:root ratio. However this was not so for Douglasfir, grown at Campbell River nursery, which showed increased survival and growth for wide spaced trees (van den Driessche 1982). There is also some doubt whether a smaller shoot:root ratio confers any survival or growth advantage on nursery stock (Racey et al. 1983).

Under some conditions wider spacing results in greater nitrogen $(\mathrm{N})$ concentration in seedlings (van den Driessche 1984). The better growth of wide spaced seedlings following planting may therefore be due to higher nutrient content, although this is certainly not always true.

Wider spacing results in greater root collar diameter and this is usually positively correlated with survival and growth after planting (Mullin and Svaton 1972, Bacon et al. 1977.
Bowles 1981, van den Driessche 1982, Racey et al. 1983). Spacing can account for much of the variation in stem diameter occurring in nursery beds. A linear correlation between root collar diameter and spacing, in drills $15 \mathrm{~cm}$ apart, gave an $r^{2}$ value of 0.7 , over a spacing range of 0.6 to $12 \mathrm{~cm}$, for Douglas-fir (van den Driessche 1982). Wider spacing also results in lower height:diameter ratios which have been considered indicative of seedling quality (Smith and Allen 1962 , Bowles 1981). This work showed that height:diameter ratios varied between species. At similar spacings the ratios shown by white spruce and lodgepole pine were lower than those of Douglas-fir.

Achieving a chosen precise spacing in 2-0 crops by precision sowing is difficult under current conditions because 10 to $20 \%$ of the seed used is not viable, and some mortality usually occurs among overwintering 1-0 crops. In fact wide spacing itself accentuates winter loss from frost heaving, and largely precludes wide spacing of white spruce in some nurseries. Even without these problems the machines currently available do not space seed precisely, although some are better than others. However they greatly increase the uniformity of seed spacing compared with previous machines and allowed seed to be sown at a suitable mean spacing to produce good quality stock.

Evidence for an optimum spacing was presented for precision sown Pinus radiata (Bowles 1981). Maximum height growth two years after planting was associated with an intermediate spacing, not the widest spacing. The Sitka spruce results provide no indication of this, although very wide average spacing was employed. Of course, species, nursery climate and soil, fertilizer regime and cultural practices may all interact with spacing. In particular, the age, and therefore size, to which the stock is to be grown is likely to influence the effect of spacing. For example, growth response of interior Douglasfir and white spruce ceased at a closer spacing in the nursery than the more rapidly growing Sitka spruce, western red cedar and coastal Douglas-fir.

Outplanting performance of white spruce stock in experiment 1 improved when stock with a mean root collar diameter of $5.8 \mathrm{~mm}$ was used. In experiment 2 Sitka spruce with root collar diameters in the range of $5.5 \mathrm{~mm}$ to $6.5 \mathrm{~mm}$ showed better performance after planting. Other evidence (van den Driessche 1982) suggests that gains in quality can be expected when stock has a root collar diameter of at least $6 \mathrm{~mm}$. Examination of yields in relation to spacing indicated that, in drills $15 \mathrm{~cm}$ apart, root collar diameters of about $6 \mathrm{~mm}$ could be achieved if spacing within drills was between 2 and $5 \mathrm{~cm}$ at sowing. Wider spacings to $2-5 \mathrm{~cm}$, between seeds in the drill, can probably be justified if diameter culling values are increased by $35-70 \%$. Increase in height culling values will have less or no effect in justifying wider spacing because wider spacing may not increase height much. In any case, the possible desirability of low height:diameter ratios would support the increase of diameter, but not height culling values. The most economical spacing to achieve the particular root collar diameter culling standard still has to be determined for each species and nursery. An increase in spacing from the present $0.6-1.0 \mathrm{~cm}$ would, of course, necessitate an almost proportional increase in nursery bed area. The increase in area might not have to be exactly proportional because better outplanting performance might mean fewer seedlings are required, and precision sowing may result in greater uniformity and therefore fewer culls. In fact one experiment showed that increasing the spacing of 3-0 black spruce (Picea mariana (Mill.) B.S.P.) from $1.5 \mathrm{~cm}$ to $6 \mathrm{~cm}$ raised production costs approximately 2.6 times (Wynia and McClain 1981). Whether the final gains at harvest justify such an increased cost is unknown. However, based on data of Table 1 and present 
results, suitably increased spacing can be expected to increase survival about $10-15 \%$ on severe sites, and similarly increase total height on all sites three years after planting.

\section{Acknowledgements}

The author gratefully acknowledges assistance of M. Balderston, D. Ponsford and R. Planden, cooperation of Silviculture Branch nursery staff and advice from Research Branch Biometrics staff in various aspects of this work. Planting of white spruce at Wansa Lake was carried out by $\mathrm{H}$. Coates, through arrangement with L. Herring, Ministry of Forests, Prince George. The Naka Creek planting site was generously made available by Western Forest Products.

\section{References}

Bacon, G.J., P.J. Hawkins and D. Jermyn. 1977. Morphological grading studies with 1-0 slash pine seedlings. Australian For. 40: 293-303.

Balderston, M.B. 1972. Photo-electric measurement of Douglas-fir needle area. Can. J. For. Res. 2: 374-376.

Balneaves, J.M. 1983. Effect of precision sowing on growth of Pinus radiata seedlings at Edendale nursery. NZJ For. 28: 93-99.

Benson, D.A. and K.R. Shepherd. 1976. Effect of nursery practice on Pinus radiata seedling characteristics and field performance: I. Nursery seedbed density. NZJ For. Sci. 6: 19-26.

Bowles, G.P. 1981. Nursery spacing and seedling quality. In Forest nursery and establishment practice in New Zealand. New Zealand Forest Service FRI Symposium 22. p. 101-112.

Burdett, A.M. 1979. New methods for measuring root growth capacity: Their value in assessing lodgepole pine stock quality. Can. J. For. Res. 9: 63-67.

Burdett, A.N., D.G. Simpson and C.F. Thompson. 1983. Root development and plantation establishment success. Plant and Soil 71: 103-110.

Chavasse, C.G.R. 1980. The means to excellence through plantation establishment: The New Zealand experience. In Forest plantations: the shape of the future. Editied by D.D. Lloyd. Weyerhaeuser Science Symposium 1. p. 119-137.
Derr, H.J. 1955. Seedbed density affects longleaf pine survival and growth. US Forest Service. Tree Planters' Notes 20: 28-29.

Mullin, R.E. and L. Bowdery. 1977a. Effects of seedbed density and nursery fertilization on survival and growth of 3-0 white pine. US Forest Service. Tree Planters' Notes.

Mullin, R.E. and L. Bowdery. 1977b. Effects of seedbed density and nursery fertilization on survival and growth of white spruce. For. Chron. 53: 83-86

Mullin, R.E. and L. Bowdery. 1978. Effects of nursery seedbed density and topdressing fertilization on survival and growth of $3+0$ red pine. Can. J. For. Res. 8: 30-35.

Mullin, R.E. and J. Svaton. 1972. A grading study with white spruce nursery stock. Common. For. Rev. 51: 62-69.

Racey, G.D., C. Glerum and R.E. Hutchison. 1983. The practicality of top-root ratio in nursery stock characterization. For. Chron. 59: $240-243$.

Shipman, R.D. 1964. Low seedbed densities can improve early height growth of planted slash and loblolly pine seedlings. $J$. For. 62: 814-817.

Shoulders, E. 1961. Effect of nursery bed density on loblolly and slash pine seedlings. J. For. 59: 576-579.

Smith, J.H.G. and G.S. Allen. 1962. Improvement of Douglas-fir planting stock. Univ. of BC Fac. Forestry Res. Pap. 55. p. 1-16

Switzer, G.L. and L.E. Nelson. 1963. Effects of nursery fertility and density on seedling characteristics, yield, and field performance of loblolly pine (Pinus taeda L.). Soil Sci. Soc. Amer. Proc. 27: 461-464

van den Driessche, R. 1982. Relationship between spacing and nitrogen fertilization of seedlings in the nursery, seedling size, and outplanting performance. Can. J. For. Res. 12: 865-875.

van den Driessche, R. 1983. Growth, survival, and physiology of Douglas-fir seedlings following root wrenching and fertilization. Can. J. For. Res. 13: 270-278.

van den Driessche, R. 1984. Relationship between spacing and nitrogen fertilization of seedlings in the nursery, seedling mineral nutrition, and outplanting performance. Can. J. For. Res. (in press).

Wynia, A. and K.M. McClain. 1981. How seedbed density can affect nursery stock costs. For. Chron. 57: 276-278.

Errata: Dans l'article "Testament d'un vieux pin blanc» (For. Chron. October, 1984), il faudrait lire les paragraphes suivants (p. 272):

Ce vieux pin blanc, dans son testament écrit sur sa souche, nous livre plusieurs enseignements pleins de sagesse pour l'aménagement des forêts.

Laissons-le parler un peu!

avant les trois bulles de la page 271 . 